\title{
KEPUTIHAN PADA WANITA
}

\author{
Gusti Ayu Marhaeni \\ Dosen Jurusan KebidananPoliteknik Kesehatan Denpasar \\ gamarhaeni@yahoo.com
}

\begin{abstract}
Leucorrhea is a condition that is often suffering by women throughout the life cycle starting from adolescence, the reproductive period or menopause. Leucorrhea divided into two types: normal vaginal discharge or physiological and pathological abnormal. Abnormal vaginal discharge or a physiologically occurs in accordance with the female reproductive cycle or in accordance with the cycle of a woman's body with this type of expenditure is actually clear, odorless not excessive and does not cause itching or burning. While the pathological or abnormal vaginal discharge is characterized by the amount of release that much, such as sour milk, yellow or greenish, itching, burning, with a fishy smell or bad odor. The color of the vagina will be different according to the cause of vaginal discharge. The most common cause of abnormal vaginal leucore is: bacteria, fungi and parasites. Prevention of vaginal leucore the most important thing to do is maintain the cleanliness of the reproductive organs in the right way, a balance between activity and rest, reduce the of vaginal discharge are bacteria, fungi and parasite and also maintaining psycologycal stress. The purpose of this paper to discover the causes of vaginal leucorrhea. Method used was to search literature related leucorrhea. The search results show the causes are bacteria, fungi and paracites.
\end{abstract}

Keywords: leucorrhea, vaginal discharge, woman

\begin{abstract}
Abstrak. Keputihan merupakan kondisi yang sering dialami oleh wanita sepanjang siklus kehidupannya mulai dari masa remaja, masa reproduksi maupun masa menopause. Keputihan dibedakan menjadi 2 jenis yaitu keputihan normal atau fisiologis dan abnormal atau patologis. Keputihan normal atau fisiologis terjadi sesuai dengan siklus reproduksi wanita atau sesuai dengan siklus tubuh wanita dengan jenis pengeluaran berwarna bening, tidak berlebihan tidak berbau dan tidak menimbulkan rasa gatal atau perih. Sedangkan keputihan yang patologis atau abnormal ditandai dengan jumlah pengeluaran yang banyak, berwarna putih seperti susu basi, kuning atau kehijauan, gatal, perih, dan disertai bau amis atau busuk. Warna pengeluaran dari vagina akan berbeda sesuai dengan penyebab dari keputihan. Penyebab keputihan abnormal yang tersering adalah: bakteri, jamur dan parasit. Pencegahan keputihan yang terpenting harus dilakukan adalah menjaga kebersihan organ reproduksi dengan cara yang benar, menyeimbangkan antara aktifitas dan istirahat, mengurangi ketegangan psikis yang dialami. Tujuan dari penulisan ini untuk menemukan faktor penyebab keputihan. Metode penulisan yang digunakan adalah dengan penelusuran pustaka terkait keputihan. Hasil penelusuran menunjukkan faktor penyebab keputihan adalah bakteri, jamur dan parasit.
\end{abstract}

Kata kunci: keputihan, pengeluaran pervaginam, wanita 


\section{Pendahuluan}

Keputihan atau yang disebut juga dengan istilah white discharge atau vaginal discharge, atau leukore atau flour albus. Keputihan yang terjadi pada wanita dapat bersifat normal dan abnormal. Keputihan normal terjadi sesuai dengan proses menstruasi. Gejala keputihan yang normal adalah tidak berbau, jernih, tidak gatal, dan tidak perih. Keputihan abnormal terjadi akibat infeksi dari berbagai mikroorganisme, antara lain bakteri, jamur, dan parasit. ${ }^{1}$ Keputihan yang tidak normal ditandai dengan jumlah yang keluar banyak, berwarna putih seperti susu basi, kuning atau kehijauan, gatal, perih, dan disertai bau amis atau busuk. Warna pengeluaran dari vagina akan berbeda sesuai dengan penyebab dari keputihan. $^{2}$

Wanita yang mengalami keputihan tidak normal merupakan indikasi dari berbagai penyakit seperti vaginitis, kandidiasis, dan trikomoniasis yang merupakan salah satu dari gejala Penyakit Menular Seksual (PMS) terutama pada wanita yang pernah berganti pasangan seksual atau pasangan seksualnya berganti pasangan seksual. Daili (2009) memaparkan Penyakit menular seksual (PMS) seperti gonore mempunyai ciri-ciri keputihan yang seperti nanah. Keputihan juga merupakan indikasi dari adanya infeksi di dalam rongga panggul seperti infeksi pada saluran telur yang disertai sakit perut yang hebat. ${ }^{3}$ Keputihan abnormal yang tidak tertangani dengan baik dan dialami dalam waktu yang lama akan berdampak pada terjadinya infeksi saluran reproduksi. Infeksi saluran reproduksi ini mengakibatkan infertilitas. ${ }^{4}$

Sobel dari Wayne State University, menulis $75 \%$ wanita di dunia mengalami keputihan paling tidak sekali dalam siklus kehidupannya dan $45 \%$ wanita mengalami keputihan sebanyak dua kali atau lebih selama siklus kehidupannya. ${ }^{5}$

\section{Pembahasan}

Leukorea berasal dari kata Leuco yang berarti benda putih yang disertai dengan akhiran -rrhea yang berarti aliran atau cairan yang mengalir. Leukorea atau flour albous atau keputihan atau vaginal discharge merupakan semua 
pengeluaran dari kemaluan yang bukan darah. Keputihan merupakan salah satu tanda dari proses ovulasi yang terjadi di dalam tubuh. Selain itu, keputihan juga merupakan salah satu tanda dari suatu penyakit. ${ }^{1}$

Keputihan ada yang bersifat fisiologi dan patologis. Keputihan bersifat fisiologis yaitu keputihan yang timbul akibat proses alami dalam tubuh. Keputihan bersifat patologis yaitu keputihan yang timbul karena infeksi dari jamur, bakteri dan virus. Keputihan patologis merupakan tanda dari adanya kelainan alat repoduksi sehingga jumlah, warna, dan baunya perlu diperhatikan.

\section{Proses fisiologis keputihan}

Proses menstruasi pada wanita terjadi dalam tiga tahapan, yaitu proliferasi, sekresi, dan menstruasi. ${ }^{6}$ Pada masing-masing poses mempunyai pengaruh yang berbeda terhadap endometrium. Keputihan secara fisiologis terjadi sebelum menstruasi karena pengaruh dari proses menstruasi yang melibatkan hormon estrogen dan progesteron. Pada proses proliferasi terjadi pembentukan hormon estrogen oleh ovarium yang menyebabkan pengeluaran sekret yang berbentuk seperti benang, tipis dan elastis. Hormon estrogen berperan dalam produksi sekret pada fase sekretorik, merangsang pengeluaran sekret pada saat wanita terangsang serta menentukan kadar zat gula dalam sel tubuh (glikogen). Glikogen digunakan untuk proses metabolisme pada bakteri Lacto bacillus doderlein. Sisa dari proses metabolisme ini akan menghasilkan asam laktat yang menjaga keasaman vagina yaitu 3,8-4,2. Pada saat ovulasi terjadi proses sekresi pada endometrium yang dipengaruhi oleh hormon progesteron. Hormon progesteron menyebabkan pengeluaran sekret yang lebih kental seperti jeli. $^{7}$

Kemaluan wanita merupakan tempat yang paling sensitif dan merupakan tempat yang terbuka sehingga kuman sangat mudah masuk. Secara anatomi alat kelamin wanita berdekatan dengan anus dan uretra sehingga kuman yang berasal dari anus dan uretra tersebut sangat mudah masuk. Kuman yang masuk ke alat kelamin wanita akan menyebabkan infeksi sehingga dapat menyebabkan keputihan patologis 
yang ditandai dengan gatal, berbau, dan berwarna kuning kehijauan.

Vagina wanita dilengkapi dengan barrier alami yaitu epitel yang cukup tebal, glikogen, dan bakteri Lactobacillus doderlein yang menghasilkan asidum laktidum sehingga vagina menjadi asam dan memperkuat daya tahan vagina. Vagina normal mempunyai bakteri Lactobacillus doderlein lebih banyak yaitu $95 \%$ dan bakteri lainnya yaitu $5 \% .^{3}$ Wanita yang memakai sabun vagina secara terus menerus dapat membunuh barrier alami vagina karena cairan pencuci vagina besifat basa. Berkurangnya bakteri Lacto bacillus doderlein dalam vagina menyebabkan bakteri dan jamur lain mudah berkembang dalam vagina hingga dapat menyebabkan infeksi.

Glikogen banyak terdapat pada sel superfisial mukosa vagina sejak bayi hingga wanita mencapai menopause. Vagina wanita yang tidak hamil dijaga kelembabannya oleh sekret uterus, sedangkan pada saat hamil terdapat sekret vagina yang asam dalam jumlah yang banyak. Bakteri Lactobacillus doderlein pada wanita yang hamil lebih banyak daripada wanita yang tidak hamil sehingga menyebabkan banyak pengeluaran sekret. Peningkatan ini yang menyebabkan pada wanita hamil sering mengalami peningkatan keputihan ${ }^{7}$.

\section{Jenis keputihan}

Keputihan dapat dibedakan menjadi dua jenis keputihan yaitu: keputihan normal (fisiologis) dan keputihan abnormal.

\section{Keputihan normal}

Keputihan normal dapat terjadi pada masa menjelang menstruasi, pada sekitar fase sekresi antara hari ke 10-16 menstruasi. Keputihan yang fisiologis terjadi akibat pengaruh hormon estrogen dan progesteron yang dihasilkan selama proses ovulasi. Setelah ovulasi, terjadi peningkatan vaskularisasi dari endometrium yang menyebabkan endometrium menjadi sembab. Kelenjar endometrium menjadi berkelok-kelok dipengaruhi oleh hormon estrogen dan progesteron dari korpus luteum sehingga mensekresikan cairan jernih yang dikenal dengan keputihan ${ }^{8}$.

Hormon estrogen dan progesteron juga menyebabkan lendir servik menjadi lebih encer 
sehingga timbul keputihan selama proses ovulasi. Pada servik estrogen menyebabkan mukus menipis dan basa sehingga dapat meningkatkan hidup serta gerak sperma, sedangkan progesteron menyebabkan mukus menjadi tebal, kental, dan pada saat ovulasi menjadi elastis. Keputihan fisiologis terdiri atas cairan yang kadang-kadang berupa mukus yang mengandung banyak epitel dengan leukosit yang jarang. Ciri-ciri dari keputihan fisiologis adalah cairan berwarna bening, kadang-kadang putih kental, tidak berbau, dan tanpa disertai dengan keluhan, seperti rasa gatal, nyeri, dan terbakar serta jumlahnya sedikit ${ }^{2}$.

Faktor-faktor yang dapat menyebabkan keputihan fisiologis adalah 1) Bayi yang baru lahir kirakira 10 hari, keputihan ini disebabkan oleh pengaruh hormon estrogen dari ibunya; 2) Masa sekitar menarche atau pertama kalinya haid datang, keadaan ini ditunjang oleh hormon estrogen; 3) Masa di sekitar ovulasi karena poduksi kelenjarkelenjar rahim dan pengaruh dari hormon estrogen serta progesterone; 4) Seorang wanita yang terangsang secara seksual. Ransangan seksual ini berkaitan dengan kesiapan vagina untuk menerima penetrasi senggama, vagina mengeluarkan cairan yang digunakan sebagai pelumas dalam senggama; 5) Kehamilan yang mengakibatkan meningkatnya suplai darah ke vagina dan mulut rahim, serta penebalan dan melunaknya selaput lendir vagina; 6) Akseptor kontrasepsi pil yang mengandung hormon estrogen dan progesteron yang dapat meningkatkan lendir servik menjadi lebih encer; 7) Pengeluaran lendir yang bertambah pada wanita yang sedang menderita penyakit kronik.

\section{Keputihan abnormal}

Keputihan abnormal dapat terjadi pada semua infeksi alat kelamin (infeksi bibir kemaluan, liang senggama, mulut rahim, jaringan penyangga, dan pada infeksi karena penyakit menular seksual). Ciri-ciri keputihan patologik adalah terdapat banyak leukosit, jumlahnya banyak, timbul terus menerus, warnanya berubah (biasanya kuning, hijau, abu-abu, dan menyerupai susu), disertai dengan keluhan (gatal, panas, dan nyeri) serta berbau (apek, amis, dan busuk) ${ }^{3}$. 
Faktor-faktor yang memicu keputihan abnormal adalah :

\section{Kelelahan fisik}

Kelelahan fisik merupakan kondisi yang dialami oleh seseorang akibat meningkatnya pengeluaran energi karena terlalu memaksakan tubuh untuk bekerja berlebihan dan menguras fisik. ${ }^{9}$ Meningkatnya pengeluaran energi menekan sekresi hormon estrogen. Menurunnya sekresi hormon estrogen menyebabkan penurunan kadar glikogen. Glikogen digunakan oleh Lactobacillus doderlein untuk metabolisme. Sisa dari metabolisme ini adalah asam laktat yang digunakan untuk menjaga keasaman vagina. Jika asam laktat yang dihasilkan sedikit, bakteri, jamur, dan parasit mudah berkembang.

\section{Ketegangan psikis}

Ketegangan psikis merupakan kondisi yang dialami seseorang akibat dari meningkatnya beban pikiran akibat dari kondisi yang tidak menyenangkan atau sulit diatasi 9 . Meningkatnya beban pikiran memicu peningkatan sekresi hormon adrenalin. Meningkatnya sekresi hormon adrenalin menyebabkan penyempitan pembuluh darah dan mengurangi elastisitas pembuluh darah. Kondisi ini menyebabkan aliran hormon estrogen ke organorgan tertentu termasuk vagina terhambat sehingga asam laktat yang dihasilkan berkurang. Berkurangnya asam laktat menyebabkan keasaman vagina berkurang sehingga bakteri, jamur, dan parasit penyebab keputihan mudah berkembang ${ }^{2}$. Penelitian Agustiyani D. dan Suryani (2011) di Yogyakarta menemukan bahwa remaja yang tingkat stressnya sedang bahkan tinggi lebih mudah mengalami keputihan ${ }^{10}$.

\section{Kebersihan diri}

Kebersihan diri merupakan suatu tindakan untuk menjaga kebersihan dan kesehatan untuk kesejahteraan fisik dan psikis, ${ }^{1}$ Keputihan yang abnormal banyak dipicu oleh cara wanita dalam menjaga kebersihan dirinya, terutama alat kelamin. Kegiatan kebersihan diri yang dapat memicu keputihan adalah penggunaan pakaian dalam yang ketat dan berbahan nilon, cara membersihkan alat kelamin (cebok) yang tidak benar, penggunaan sabun vagina dan 
pewangi vagina, penggunaan pembalut kecil yang terus menerus di luar siklus menstruasi. Penelitian di Pondok Cabe Ilir Jakarta menemukan bahwa remaja yang mempunyai pengetahuan rendah, sikap yang jelek dan perilaku buruk dalam menjaga kebersihan akan memperburuk kondisi keputihan abnormal. ${ }^{11}$

\section{Dampak keputihan}

Keputihan fisiologis dan patologis mempunyai dampak pada wanita. Keputihan fisiologis menyebabkan rasa tidak nyaman pada wanita sehingga dapat mempengaruhi rasa percaya dirinya. Keputihan patologis yang berlangung terus menerus akan menganggu fungsi organ reproduksi wanita khususnya pada bagian saluran indung telur yang dapat menyebabkan infertilitas. Pada ibu hamil dapat menyebabkan keguguran, Kematian Janin dalam Kandungan (KJDK), kelainan kongenital, lahir premature. ${ }^{4}$

\section{Cara mencegah keputihan}

Menjaga kebersihan alat kelamin

Vagina secara anatomis berada di antara uretra dan anus. Alat kelamin yang dibersihkan dari belakang ke depan dapat meningkatkan resiko masuknya bakteri ke dalam vagina. Masuknya kuman ke dalam vagina menyebabkan infeksi sehingga dapat menyebabkan keputihan. Cara cebok yang benar adalah dari depan ke belakang sehingga kuman yang berada di anus tidak dapat masuk ke dalam vagina.

\section{Menjaga kebersihan pakaian dalam}

Pakaian dalam yang tidak disetrika dapat menjadi alat perpindahan kuman dari udara ke dalam alat kelamin. Bakteri, jamur, dan parasit dapat mati dengan pemanasan sehingga menyetrika pakaian dalam dapat menghindarkan infeksi kuman melalui pakaian dalam.

\section{Tidak bertukar handuk}

Handuk merupakan media penyebaran bakteri, jamur, dan parasit. Handuk yang telah terkontaminasi bakteri, jamur, dan parasit apabila digunakan bisa menyebabkan kuman tersebut menginfeksi pengguna handuk tersebut sehingga gunakan handuk untuk satu orang.

\section{Menghindari celana ketat}

Celana ketat dapat menyebabkan alat kelamin menjadi hangat dan lembab. Alat kelamin yang lembab 
dapat meningkatkan kolonisasi dari bakteri, jamur, dan parasit. Peningkatan kolonisasi dari kuman tersebut dapat meningkatkan infeksi yang bisa memicu keputihan, maka hindari memakai celana ketat terlalu lama.

\section{Menghindari cuci vagina}

Produk cuci vagina dapat membunuh flora normal dalam vagina. Ekosistem dalam vagina terganggu karena produk pencuci vagina bersifat basa sehingga menyebabkan kuman dapat berkembang dengan baik. Produk cuci vagina yang digunakan harus sesuai dengan $\mathrm{pH}$ normal vagina, yaitu 3,8-4,2 dan sesuai dengan petunjuk dokter.

Mencuci tangan sebelum mencuci alat kelamin

Tangan dapat menjadi perantara dari kuman penyebab infeksi. Mencuci tangan sebelum menyentuh alat kelamin dapat menghindarkan perpindahan kuman yang menyebabkan infeksi

\section{Sering menganti pembalut}

Mengganti pembalut minimal 3-4 kali sehari dapat menghindari kelembaban.

\section{Mengelola stress}

Stres dapat meningkatkan hormon adrenalin yang menyebabkan penyempitan pembuluh darah. Pembuluh darah yang sempit menyebabkan aliran estrogen ke vagina terhambat sehingga dengan menghindari stres dapat mengurangi keputihan.

\section{Simpulan dan Saran}

Keputihan pada wanita dapat dibedakan menjadi 2 jenis yaitu keputihan fisiologis dan keputihan pathologis. Keputihan fisiologis terjadi sesuai siklus menstruasi dan keputihan pathologis disebabkan oleh mikroorganisme baik bakteri, jamur dan parasit. Dampak yang timbul akibat keputihan adalah ketidaknyamanan pada wanita dan akibat yang berat adalah infertilitas.

Disarankan agar semua wanita menjaga kebersihan diri dengan benar, mengelola stress dan menyeimbangkan aktifitas fisik dan istirahat.

\section{Daftar Pustaka}

1. Manuaba I.A.C., Manuaba IBG, Manuaba IB. Memahami Kesehatan Reproduksi Wanita. 2nd ed. Jakarta: EGC; 2009.

2. Wiknjosastro H. Ilmu Kandungan. Jakarta: Yayasan 
Bina Pustaka Sarwono Prawirohardjo; 2007.

3. Daili, Fahmi S, Indriatmi B. Penyakit Menukar Seksual. Jakarta: Balai Penerbit Fakultas Kedokteran Indonesia; 2009.

4. Kasdu D. Solusi Problem Wanita Dewasa. Jakarta: Puspa Swara; 2008.

5. Ariev. Agar Keputihan Tidak Berulang. 2012 Mar 14; Available from: http://www. gealgeol.com/2008/08/27/agarkeputihan-tak-berulang.html

6. Saifuddin A. Ilmu Kebidanan. Jakarta: Yayasan Bina Pustaka Sarwono Prawirohardjo; 2008.

7. Bobak. Buku Ajar Keperawatan Maternitas. Jakarta: EGC; 2005.

8. Benson RC. Buku Saku Obstetri dan Ginekologi. Jakarta: EGC; 2009.

9. Anonim. Keterampilan Hidup (Life Skill) dalam Program Penyiapan Kehidupan Berkeluarga Bagi Remaja. Jakarta: BK; 2010.

10.Agustiyani D, Suryani. Hubungan Tingkat Stress dengan Kejadian Keputihan pada Remaja PutriKelas X dan XI di SMA Taman Madya Jetis Yogyakarta [Internet]. Yogyakarta; 2011. Available from: http://opac.unisa yogya.ac.id/1028/1/NASKAH PUBLIKASI.pdf

11. Nurhayati A. Hubungan Pengetahuan, Sikap, Dan Perilaku Vaginal Hygiene Terhadap Kejadian Keputihan Patologis Pada Remaja Putri Usia 13-17 Tahun Di Daerah Pondok Cabe Ilir [Internet]. Jakarta; 2013. Available from: http://repository. uinjkt.ac.id/dspace/bitstream/123 456789/26343/1/Annisa

Nurhayati-fkik.pdf 